\title{
Poética modulada
}

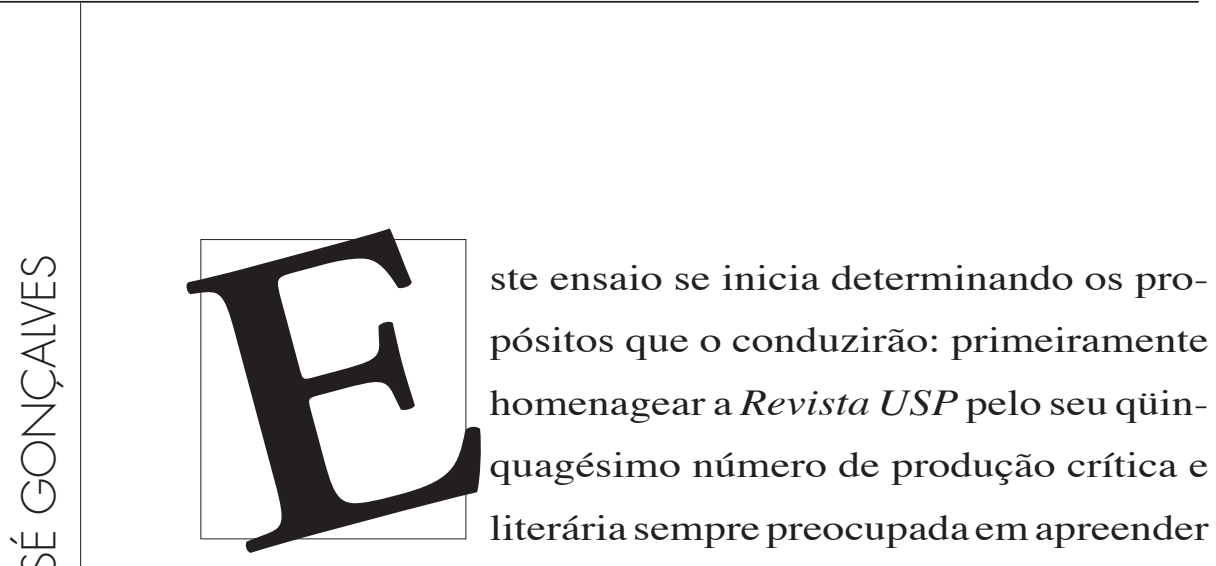

e apresentar o que há de mais relevante no pensamento crítico da literatura nacional e internacional; depois, dar continuidade a uma questão de estética ou de poética que vem dominando nosso pensamento há algum tempo: trata-se do procedimento de modulação em arte e, especificamente, em literatura. Escrevemos sobre o assunto no número 81-82 do Bulletin des Études Valéryennes (Université Paul Valèry, Montpellier III), publicado em 1999, cujo dossiê especial foi Mallarmé / Valéry: Poétiques pelos cem anos de morte de Stéphane Mallarmé. O ensaio denominado Stéphane Mallarmé, Paul Valéry: une Pensée Abstraite quis prestar uma homenagem ao pensamento 
AGUINALDO JOSÉ GONÇALVES é professor de Teoria Literária e de Literatura Comparada da Unesp - campus de São José do Rio Preto - e autor de, entre outros, Transição e Permanência. Miró/João Cabral: da Tela ao Texto (lluminuras) $e$ Vermelho (Ateliê Editorial). poético de Mallarmé que teve continuidade em Valéry tratando de uma questão extremamente cara ao compositor de Un Coup de Dés... : os aspectos da modulação em poesia. Ao me dispor, portanto, à escritura desteensaio, voltei ao mesmo motivo, mas agora tendo como objeto a poética de Marcel Proust anunciando algumas conexões com a de Machado de Assis. Éevidente que nos referimos àquelas obras dos dois autores que atingiram alto grau de modulação; respectivamente: Em Busca do Tempo Perdido e os cinco últimos romances de Machado de Assis.

Portanto, a raiz deste ensaio estáno outro, inspirado em pontos esparsos de algumas reflexões do poeta francês correspondentes às idéias ressonantes nos poucos fragmentos escritos pelo pintor Paul Cèzanne ao também refletir sobre o processo de composição da pintura - a questão da modulação como terceira e última etapa do trabalho artístico. A correspondência entre as idéias desses dois mestres da modernidade aponta para uma questão decisiva da poética contemporânea que deita luz nas questões da criação artística. Mallarmé e Cézanne realizaram uma obra modulada em alto grau e sobre isso refletiram. Com isso haveriam de iluminar o que estava por vir: todo o trilhar do século XX, com suas luzes e sombras indiscutivelmente fantásticas que acabamos de vivenciare que ainda ressoa em nossos ouvidos e em nosso corpo inteiro dele imbuído e nele refletido, com os braços abertos, e com unhas enormes arranhando as paredes dos novecentos, por um lado, e, por outro, com unhas curtas, muito curtas, tentando arranhar os contornos dos últimos suspiros do século XX. Enquanto isso, com olhos baços e medrosos, pés trôpegos e asas quedas, miramos a linha do horizonte nublada e profusa deste primeiro ano do século XXI. Porémé daqui, do alto da colina deste século que, com os olhos firmes, mais uma vez voltamos a cem anos e tentamos compreender esse fundamento estético nos valendo de dois contemporâneos de 
Mallarmé: Marcel Proust e Machado de Assis. Os procedimentos construtivos da obra de arte - e seja ela de qualquer natureza-passam por determinadas etapas sem as quais o que se terá como resultado será alguma coisa que tende a querer ser arte mas que não cumpre seus intentos. Na verdade, a noção de "arquitetura" que norteia o princípio de construção da obra de arte requer três etapas ou três níveis de elaboração que, olhando sob o prisma da representação, entenderíamos como três níveis ou três instâncias da mímesis.

Na produção poética de Mallarméé possível verificar esse procedimento estético de maneira muito clara, apesar do grau de complexidade que o envolve. Como se sabe, não é extensa a obra poética de Mallarmé. Seus poemas, sobretudo alguns sonetos, foram reescritos várias vezes antes de serem publicados. Da mesma forma, quanto mais Paul Cèzanne evoluía na criação de seus quadros, avançando no seu amadurecimento estético, mais deixava de variar nos modelos utilizados, retomando em cada quadro o motivo do quadro anterior, buscando na enformação estética uma depuração no ato de modular.

\section{COMPOR, REALIZAR, MODULAR:}

\section{ALGUNS PROCEDIMENTOS CONVERGENTES EM MARCEL PROUST E MACHADO DE ASSIS}

Jamais imaginara correspondências tão profundas de formas e modos chegando a me defrontar com correspondência de $v i$ são antes de penetrar mais intimamente naqueles dois laboratórios de experiências ficcionais e/ou miméticas. Nas primeiras instâncias de leitura, sentia apenas certo perfume a distância, alguns debuxos, alguns arquipélagos de estilo que pareciam me remeter a nomes distantes em outros romances, dos dois autores, sensações se- melhantes em obras diferentes; remetiam ainda a percepções muitas vezes irônicas de personagens e trejeitos opostos de narrativas que se distinguiam muito e ao mesmo tempo se pareciam ou se remetiam: o espaço poético da narrativa de Machado de Assis e de Marcel Proust. Evidentemente, diferenças fundamentais se impõem entre as duas narrativas: parágrafos curtos em um para longos períodos que se desdobram infinitamente, em outro; as diferenças de vozes e modos narrativos que denunciam fluxos e intermeios de imagens distintas e desenhos de estilos singulares, cada um a sua maneira. Entretanto, não é semelhança de estilos que nos tomam pelas mãos para olhar para esses dois grandes narradores que foram coetâneos na passagem do século XIX para o século XX. À la Recherche du Temps Perdu é obra composta por sete volumes, que parecem criar um verdadeiro meandro divagante, em que as águas entremeiam cada ilha, e cada uma delas nomeada, individualizada (No Caminhode Swann, À Sombradas Raparigas em Flor, O Caminho de Guermantes, Sodoma e Gomorra, A Prisioneira, A Fugitiva, OTempo Redescoberto), mas ao mesmo tempo voltando sempre aos mesmos pontos, aos mesmos motivos, como na música, e ressoando uma em outra de modo tal que nos deixamos perder pelas fontes da memória voluntária, a memória da lembrança, enquanto outros redutos do imemorial parecem ressurgir do fundo e se manifestar pelas sensações mais recônditas do ser. Num brilhante ensaio denominado "Proust et les Noms", parte de Le Degré Zéro de l'Écriture suivi de Nouveaux Essais Critiques (1972), Roland Barthes, após definir À la Recherche du Temps Perdu como a "história de uma escritura", divide a obra como se se tratasse de um drama em três atos: no primeiro, enuncia-se a vontade de escrever; no segundo e longo ato enuncia-se a impotência de escrever; e, finalmente, depois de escapar-lhe todas as esperanças, o narrador se depara com todo o poder de escrever. Barthes explicita o movimento narrativo da obra, mostrando o paralelo entre o personagem narrador Marcel e o narrador que 
se vale de ingredientes da vida do autor para desenvolver a sua escritura ficcional:

“ On ne cherche pas ici à expliquer l'oeuvre de Proust par sa vie; on traite seulement d'actes intérieurs audiscours lui-même (en conséquence, poétiques et non biographiques), que ce discours soit celui du narrateur ou celui de Marcel Proust. Or, l'homologie qui, de toute évidence, règle les deux discours, appelle un dénouement symétrique: il faut qu'à la fondation de l'écriture par la réminiscence (chez le narrateur) corresponde (chez Proust) quelque découverte semblable, propre à fonder définitivement, dans sa continuité prochaine, toute l'écriture de la Recherche" (loc. cit., p. 124).

Ainda para Barthes, os dois discursos, o do narrador e o de Marcel Proust, são homólogos, mas não pontualmente análogos. Enquanto o narrador vai escrever, num ato futuro que o coloca na ordem da existência, Marcel Proust escreve, colocandose na ordem da palavra; o narrador se prende a uma psicologia; Marcel Proust se mune de uma técnica: luta com as categorias da linguagem e não com as categorias do comportamento. Machado de Assis também desenvolve uma longa narrativa que, apesar de não conferir receber, como em Proust, um nome que conjugue todos os romances (refiro-me aos cinco romances escritos a partir de 1881: Memórias Póstumas de Brás Cubas; Quincas Borba; Dom Casmurro; Esaú e Jacó e Memorial de Aires), revela uma notável relação que forma no conjunto da obra um verdadeiro périplo, marcado, como em Proust, não com as categorias do comportamento mas com as categorias da linguagem. Essas categorias da linguagem, em Machado, focalizam, sobretudo, o trabalho do narrador; a dimensão discursiva desenvolvida numa poética da retórica, por procedimentos composicionais que passam a gerar semioses ilimitadas por meio do que denominaríamos de figuras. O universo das reminiscências do narrador é da ordem das referências do mundo que se transmudam uma vez postas em condição de linguagem; do mesmo modo se constrói o universo proustiano, pertencente a uma esfera essencialmente poética. Entretanto, é necessário que ambos os universos, o das reminiscências e o do fato lingüístico, tenham o poder de constituir a essência dos objetos romanescos. O saber distinguir e ao mesmo tempo relacionar o entrecruzar dos dois discursos que formam a narrativa parece-nos relevante para que se possam compreender suas vozes. Discursos que encontraram nos procedimentos mais variados e conjugados da linguagem os caminhos para que se fizessem emergir, com a profundidade devida, as categorias da memória e as fabricações de espaços difíceis de se criar, a não ser pelos caminhos trilhados pelo escritor.

O laboratório inventivo de Machado de Assis durou por volta de vinte anos (entre os anos 60 e 80). Ele se constituiu dos variados gêneros desenvolvidos pelo autor. Entendemos não ter sido ao acaso o fato de ele ter se exercitado em tantas formas de criar: as crônicas, os contos, as poesias, o teatro com características que jamais ousaria chamar de românticas; exercícios de crítica literária, chegando até mesmo a realizar grandes ensaios como é o caso de "Primo Basílio" e "Espírito de Nacionalidade".

A consciência de Proust sobre o valor dos signos e do poder que possui o artista em metamorfoseá-los em signo estético manifesta-se, não apenas no efeito expressivo de sua obra, mas também em várias passagens em que mais declaradamente expõe suas idéias sobre arte e invenção. Pode-se dizer que essa consciência coincide com seu modo de conceber o estilo, que se relaciona diretamente à visão: "o estilo para o escritor como para o pintor é um problema, não de técnica, mas de visão" (T. R., p. 142). E isso se concretiza pelo caminho da própria arte que se fabrica e se apresenta como único meio de leitura dessa inexorável condição. Essa crítica interna ao próprio trabalho poético-ficcional talvez seja o ponto alto da conjunção construtiva dos dois escritores. De uma maneira mais determinada, Machado de Assis desenvolveu um trabalho crítico mais defi- 
nido. Em Marcel Proust as coisas ficaram um pouco mais difusas, voltadas para as realizações de pastiches, comentários menos definidos enquanto crítica literária, prefácios que se tornaram textos ensaísticos e pequenos artigos em jornais. Mas, diferentemente de Machado, Proust realizou alguns estudos sobre autores de sua predileção como foi o caso de Flaubert, Balzac, Baudelaire, Nerval, e demonstrou sua "ira crítica” em relação a Sainte Beuve. Enfim, podemos assinalar que ambos os artistas possuem esse poder e essa competência crítica e eram genuínos leitores da tradição e de si mesmos. As forças do estilo são cabais tanto no escritor francês, quanto no brasileiro. Elas operam por simetria nesse discurso, mas se trata de uma simetria distinta daquela dos ladrilhos e dos azulejos. Em Marcel Proust o estilo denuncia uma estranha simetria, constituída por arpejos sintáticos e fricção léxico-semântica, ajustes morfológicos de substantivos e adjetivos concretos, versos interditos que parecem provocar efeitos raramente conseguidos pela poesia. Esse estilo vai deixando rastros na nossa memória vivencial e cultural por um processo remissivo, associativo. Nos romances de Machado de Assis, a força do estilo também se manifesta numa relação de profunda simetria advindo de efeito e não de lavor. A articulação composicional, ou a motivação composicional para lembrar o formalista russo B. Tomachevski, realizada na construção dos cinco romances revela uma consciência arquitetônica da literatura que poderia raramente ser comparada com outro escritor que não seja Marcel Proust. Se a obra de Proust serviu a G. Genétte como matéria-prima para a elaboração de sua teoria, provavelmente a de Machado de Assis valeria do mesmo modo para criar outro desenho teórico. Somente os jogos discursivos no que diz respeito ao foco narrativo nos cinco romances que vão de Memórias Póstumas de Brás Cubas a Memorial de Aires já merecem um capítulo especial de um estudo desta poética.

À la Recherche du Temps Perdu consiste numa espécie de laboratório cujos expe- rimentos intermináveis surtem resultados positivos, mesmo havendo concomitância de composições alquímicas. Trata-se de um procedimento que tem como objetivo apreender os filamentos da existência em suas dimensões tensivas, por meio do único instrumento de que dispõe a linguagem elevada à sua mais alta potência. À la Recherche $d u$ Temps Perdu é areia movediça que nos traga, mas não nos mata, devolvendo-nos à terra firme, alterados, mas com a sensação de termos aprendido um pouco mais sobre nossa própria condição. Esses índices metafóricos utilizados para definir o estilo de Proust parecem atuar como tratamento homeopático. É assim que também pensa Roger Shattuk, para quem talvez seja melhor ler Proust como se fosse um tipo de cura homeopática ou uma iniciação a estranhos movimentos físicos e mentais desenvolvidos por uma outra cultura. "Um compasso uniforme, vagaroso, sem a tensão de prazos estabelecidos, é mais conveniente. Certos hábitos de pensamento podem, assim, ser postos de lado, enquanto outros são adquiridos. Isso pode levar meses e até anos. A Busca cria uma estação da mente fora dos limites temporais" (1985, p. 32).

Mas esses movimentos físicos e mentais a que se refere Shattuk manifestados por índices metafóricos podem ser vistos e lidos em muitas das passagens da obra de Machado de Assis. Seriam as "pérolas" de que fala Shattuk comentando o estilo de Proust. À guisa de exemplo e realizando um procedimento crítico em diagonal, convido o leitor a ler ou provavelmente a reler esta conhecida passagem do romance Dom Casmurro extraída do capítulo "Olhos de Ressaca":

"Deixe ver os olhos, Capitu.

Tinha-me lembrado a definição que José Dias dera deles, 'olhos de cigana oblíqua e dissimulada'. Eu não sabia o que era oblíqua, mas dissimulada sabia, e queria ver se se podiam chamar assim. Capitu deixou-se fitar e examinar. Só me perguntava o que era, se nunca os vira; eu nada achei extraordinário; a cor e a doçura eram minhas 
conhecidas. A demora da contemplação creio que lhe deu outra idéia do meu intento; imaginou que era um pretexto para mirálos mais de perto, com os meus olhos longos, constantes, enfiados neles, e a isto atribuo que entrassem a ficar crescidos, crescidos e sombrios, com tal expressão que... Retórica dos namorados, dá-me uma comparação exata e poética para dizer o que foram aqueles olhos de Capitu. Não me acode imagem capaz de dizer, sem quebra da dignidade do estilo, o que eles foram e me disseram. Olhos de ressaca? Vá, de ressaca. É o que me dá idéia daquela feição nova. Traziam não sei que fluido misterioso e enérgico, uma força que arrastava para dentro, como a vaga que se retira da praia, nos dias de ressaca. Para não ser arrastado, agarrei-me às outras partes vizinhas, às orelhas, aos braços, aos cabelos espalhados pelos ombros, mas tão depressa buscava as pupilas, a onda que saía delas vinha crescendo, cava e escura, ameaçando envolver-me, puxar-me e tragar-me. Quantos minutos gastamos naquele jogo? Só os relógios do céu terão marcado esse tempo infinito e breve. A eternidade tem as suas pêndulas; nem por não acabar nunca deixa de querer saber a duração das felicidades e dos suplícios. Há de dobrar o gozo aos bemaventurados do céu conhecer a soma dos tormentos que já terão padecido no inferno os seus inimigos; assim também a quantidade das delícias que terão gozado no céu os seus desafetos aumentará as dores aos condenados do inferno. Este outro suplício escapou ao divino Dante; mas eu não estou aqui para emendar poetas. Estou para contar que, ao cabo de um tempo não marcado, agarrei-me definitivamente aos cabelos de Capitu, mas então com as mãos, e disselhe, - para dizer alguma cousa, - que era capaz de os pentear, se quisesse.

- Você?

- Eu mesmo.

- Vai embaraçar-me o cabelo todo, isso sim.

- Se embaraçar, você desembaraça depois.

- Vamos ver."

Não é o propósito deste texto analisar a narrativa de Machado de Assis, mas vale assinalar os procedimentos poético-discursivos articulados da primeira à última palavra que compõem esse tecido que parece mais espesso que os cabelos de Capitu, que na verdade metaforizam os fios da literariedade nas mãos do narrador do romance. A obliqüidade ou a dissimulação dos olhos de Capitu correspondem à própria obliqüidade ou dissimulação do capítulo ou da própria literatura, vista no seu movimento natural, ou seja, no seu movimento centrípeto, na lúcida concepção de Northrop Frye. Ao pseudo-ironizar seu discurso como sendo "retórica dos namorados", metapoeticamente o narrador entra para uma espécie de esfera mítica da linguagem, que se vale dos olhos mergulhados nos olhos de ressaca e vai construindo o que Proust denominaria de "metáfora precisa", que nada mais é que linguagem em alto grau de eficácia por ter atingido um alto grau de modulação. Pois, além de ser composto, é fundamental que o texto seja modulado, para recuperar aqui os princípios de reflexão de Mallarmé e Cézanne. Durante a leitura, muitos são os momentos em que sentimos um pulsar distante de sentimentos vagos e profundos, próximos daqueles que nos provocam a música pura, mas com uma natureza própria, que mobiliza nossa memória, não a voluntária, mas a memória das sensações, de um viver não lembrado mas recordado, ou de pontos imemorializados que parecem voltar trôpegos e indefinidos e, por isso mesmo, determinantes.

No que diz respeito a Proust, tem razão Shattuk quando diz que, tanto na tradução como no original, Proust torna a maior parte de seus leitores mais lentos. Essa lentidão atua como uma espécie de reeducação do leitor que não consegue encontrar a rápida fluência na maioria dos chamados romances "realistas" do século XX, nem encontrar os procedimentos narrativos mais “atraentes" de frases curtas, por meio de técnicas mais originais, de outras tantas invenções romanescas. O discurso proustiano é difícil e longo, entretanto, envolvente e claro. 


\section{ESTLLO E VISÃO EM MARCEL PROUST}

Até aqui, anunciamos algumas correspondências entre o processo de invenção de Marcel Proust e o de Machado de Assis. Quisemos anunciá-las como uma forma de prenúncio crítico do que vimos desenvolvendo num trabalho maior. Nas páginas que se seguirão deter-nos-emos em alguns aspectos do estilo modulado de Marcel Proust até para melhor aclimatizá-lo junto ao público brasileiro.

Os setenta e cinco anos de morte do escritor francês assistem a uma proliferação cada vez maior de publicações de sua obra e de estudos a ela dedicados. Dentre as várias hipóteses que poderiam justificar este fenômeno, uma parece decisiva: a obra de Marcel Proust constitui-se de um verdadeiro sistema crítico-inventivo, em que se alinhavam outros tantos, por meio de um eixo mobilizador que suscita planos de sentidos capazes de abarcar vários níveis de compreensão. Pode-se dizer que esse eixo atua como uma metáfora nublada na marcha das palavras proustianas, cujas raízes se expandem por camadas espessas e seguras, escondidas enquanto não flagradas, e deslizantes ao se revelarem em relações de sentido amalgamadas na "arquitetura da imagem", erigida com a força do universo verbal. Suas precisas vertentes têm tido o poder de atingir as mais diferentes esferas de visão, os mais diferentes pontos de vista. A abertura de seu compasso exige passos de espera do leitor virtual. Vale, nesse sentido, lermos um fragmento do próprio Proust, extraído de seu brilhante ensaio "Sur la Lecture" que precede a edição francesa Sésame et les Lys de John Ruskin:

"Tant que la lecture est pour nous l'initriatrice dont les clefs magiques nous ouvrent au fond de nous mêmes la porte des demeures où nous n'aurions pas su pénétrer, son rôle dans notre vie est salutaire. Il devient dangereux aucontraire quand, au lieu de nous éveiller à la vie personalle de l'esprit, la lecture tend à se substituer à elle, quand la verité ne nous apparaît plus comme un idéal que nous ne pouvons réaliser que par le progrès intime de notre pensée et par l'effort de notre coeur, mais comme une chose matérielle, déposée entre les feuillets des livres comme un miel tout préparé par les autres et que nous n'avons qu'à prendre la peine d'atteindre sur les rayons des bibliothèques et de déguster passivement dans un parfait repos de corps et d'esprit' (1987, p. 73).

Marcel Proust antecipa, não apenas nesta passagem, mas em todo o texto sobre a leitura, aspectos de suma importância que seriam apenas discutidos de maneira mais sistematizada pelos teóricos da recepção alemã. Aponta, como se pode notar, para a necessidade de um dinamismo na leitura entre o leitor e o texto para que se operem as forças fundamentais para a mobilização e crescimento interior do leitor. Ao mesmo tempo critica a leitura passiva em que não se dá o processo dialógico responsável pelos atos transformadores e propulsores do nosso mundo particular. Durante toda a sua obra, sua atitude crítica se manifesta por meio das personagens, como receptoras não apenas de literatura mas também das demais artes, sobretudo a pintura. Sua visão se esparge por todos os lugares de seu trabalho de arte. É exatamente por isso que não se pode fazer, principalmente dessa obra, espaço de explicações textuais, mas espaço para o dialogismo, que fez parte de seu processo de invenção e que lhe custou todo o embasamento de sua concepção sobre arte.

Os dois pólos da linguagem (a referencialidade do discurso crítico e a poeticidade do discurso literário) encontram-se em tensão permanente, mediados pela função metalingüística. Ao mesmo tempo que "exercitava" ou "arquitetava" sua obra, mantinha-se integrado aos seus contemporâneos, atento para a visão dos mais proeminentes críticos da época, mantendo na sua mira os artistas e os críticos mais representativos do passado. Sua posição sempre foi de perquiridor, questionando e respon- 
dendo, sem radicalismos, a toda a sorte de posicionamentos. Esse permanente exercício de "limpeza" conferiu-lhe uma grande recompensa: jamais se deixou levar pelas águas da retórica fácil e cristalizada, ao contrário, execrou-a de seu território e dela apenas se valeu como recurso paródico para a construção de sua fina ironia, seja na ficção propriamente dita, seja nos ensaios quase sempre permeados de invenção, espaço em que aponta com mais transparência para os descaminhos da crítica.

O desmesurado e obsessivo respeito aos cânones, marcado pela "correção gramatical" e pela "linearidade semântica", e o distanciamento do que é singular no estilo - dois aspectos tão marcantes na maioria das produções e defendidos pela maioria da crítica - foram o "pomo de discórdia" e, ao mesmo tempo, o elemento instigador para a evolução do pensamento de Marcel Proust. Valendo-se de critérios bastante originais, deixando, na maioria das vezes, aparecer apenas a ponta afiada de sua arma branca, voltou-se, ferozmente, contra o que considerava impertinentes posições críticas, ou métodos incorretos de letrados de renome, como foi o caso de Sainte-Beuve e mesmo Anatole France. Esses e outros de notória fama acabavam exercendo no público e mesmo em escritores jovens que precisavam da sua aprovação, uma grande e muitas vezes negativa influência, embasados em posicionamentos radicais e se valendo de um modelo retórico superado e equivocado.

Todavia, como já disse, Proust não era radical. Sua inteligência mantinha-se nas asas da dialética que, como se sabe, é nada comum entre os mortais e é ao mesmo tempo a base necessária para qualquer processo de mudança evolutiva em qualquer campo do conhecimento. A ausência do pensamento dialético interfere decisivamente no comportamento crítico. Os equívocos provocados no campo das artes e da literatura por influências dessa natureza, escondidas na erudição e no comportamento autoritário, acabam por definir visões de uma época, que só mais tarde são desmascaradas. Marcel Proust conseguia ver e entender cada patamar de um juízo ou conseguia ler e refletir dentro das mais diferentes dimensões de uma obra. Demonstra, pelo seu postulado crítico, ter-se envolvido com tudo o que por ele passou, lendo Homero e Virgílio; lendo Racine e Boileau; lendo Balzac e Stendhal; lendo George Sand, Béranger, mas também George Eliot e Flaubert; lendo Hugo e Baudelaire, e assim, possuindo um pensamento comparativista por excelência, soube estabelecer as medidas para cada juízo, percebendo os grandes valores, sem jamais, mesmo em relação a eles, deixar de apontar seus pontos frágeis na construção do estilo. Acompanhava de perto as novas produções literárias e artísticas, tendo conhecimento das antigas, e era neste prisma que questionava sempre as cristalizações mentais dos intelectuais da época, assentados em modelos que poderiam ser "funcionais" enquanto modelos, mas produzidos dentro de pontos de vista reduzidos. Sendo assim, ao invés de serem úteis para uma melhor elucidação das obras, afastavam ainda mais o público leitor dos reais meandros que fazem avançar os procedimentos artísticos.

A linha mestra de Proust esteve sempre voltada para dois (ou apenas um?) alvo: perscrutar o interior das obras e reconhecer-lhes o que considerava estilo, verificando a intrincada conexão entre a obra de arte e a realidade que lhe serviu de matéria-prima. Os parênteses acima querem ter voz: o movimento de penetração numa obra, via nuanças de seus recursos estilísticos, não implicaria buscar a natureza da obra e nisso compreender sua conexão (dialética, é certo) com a realidade? Nessa indagação se encontra o núcleo da mola propulsora de todo grande artista e de todo genuíno crítico e nela Proust esteve mergulhado durante todo o tempo de sua vida de escritor e de leitor das demais artes. A escritura de Proust realiza-se, aparentemente, por um coerente processo de associações de idéias. No entanto, caminha por arquitetados meandros divagantes que mesclam suas impressões às formalizações do raciocínio, negaceando pontos frágeis e enfrentando situações delicadas, dentro de 
um turbilhão de relações que consegue estabelecer entre as mais diferentes idéias. Isso se deve a um árduo exercício que desenvolveu com a linguagem, um exercício de aproximação da linguagem, para conseguir ir, paulatinamente, rastreando a realidade, por meio das coisas e dos seres, feitos linguagem, e por ela resgatados em forma de imagem. Foi assim que se efetivou essa produção.

Um dos mais precisos ensaios sobre o escritor francês foi escrito por Ernst-Robert Curtius-e o que é curioso-em 1925, antes mesmo de que saísse a público a maior parte de sua obra. Trata-se do livro Marcel Proust y Paul Valéry (1941), obra um pouco estranha (talvez inacabada), uma vez que o grande filólogo dedica 152 das 189 páginas a Marcel Proust e apenas as restantes a Paul Valéry. Curtius não precisou de ver o conjunto da produção proustiana para entender alguns filamentos que consideramos de primeira ordem. Sua visãoé intensa no que diz respeito aos aspectos do estilo em Proust. Um outro destaque das considerações do filólogo alemão presente no seu excelente e iluminador ensaio consiste naquilo que depreendeu no discurso proustiano sobre a metáfora. Ao comentar uma passagem para transmitir o estilo do autor francês, assim se manifesta:

"Esta passagem nos ensina ainda mais, com suas duas metáforas caracteristicamente escolhidas: as trocas de cor estão comparadas com um crescendo musical, o contorno das sombras com uma vegetação. Ambas as metáforas servem para precisar o aspecto óptico do processo senso-espiritual descrito. As metáforas são em Proust um meio de alcançar uma visão completa, não se oferece ao serviço de uma coloração emocional do processo. São instrumentos de conhecimento. A consciência artística de Proust exige do seu estilo o mesmo que o sol produz na pedra: 'une ténuité dans la délinéation des moindres détails'. O estilo de Proust confirma a conclusão de Middleton Murry de que a metáfora é o resultado da busca de um epíteto preciso" (loc. cit., p. 58).
Neste caminho, cremos ser de relevante significação intercalarmos a própria crítica de Marcel Proust, para que possamos ir delineando seu pensamento e a fonte de seu estilo que foi magistralmente plasmado pela forma essencial de sua criação. Em 1920, faltando portanto um ano para a sua morte e estando já na fase madura, quase no final da realização de sua obra maior, o escritor francês publica em La Nouvelle Revue Française o ensaio “A Propósito do Estilo de Flaubert” (1994, 65-85), em resposta a um artigo de Albert Thibaudet. Logo de início, temos a sua indignação (que é reveladora de uma consciência) frente ao fato de Albert Thibaudet ter considerado Flaubert um homem sem muito talento para escrever. Com toda a sua fina ironia, Proust recebe e discute a afirmação como se fosse uma bomba desproposital que caísse sobre a Terra. Comparando as inovações de Flaubert, como sendo tão revolucionárias quanto as Categorias de Kant, passa, por meio de recursos extraídos "do lado de dentro" do estilo do autor de Madame Bovary, a argumentar em favor desse estilo e de seu criador. Parece ainda ecoar nas palavras de Curtius aquelas de Proust sobre o estilo de Flaubert. O que o fascinou em Flaubert foi exatamente o procedimento construtivo, o exercício exaustivo daquele escritor com a linguagem, em busca da expressão desejada. Para isso, era necessário uma arquitetônica forma de narrar, forma esta que Marcel Proust foi elaborando cuidadosamente. Se por um lado Proust soube reconhecer a inovadora e magnífica maneira de narrar de Gustave Flaubert, soube também notar suas falhas, ou, ao menos, aquilo que lhe faltou no estilo. Antes de passar às considerações dominantes do ensaio, isto é, às inovadoras e profundas maneiras de trabalhar os tempos verbais, os advérbios, a conjunção e outros recursos, discute o fraco processo de criação da metáfora em Flaubert; a metáfora, que para ele é o ponto fundamental para se conseguir a eternização de um estilo. Essa "lacuna" no estilo de Flaubert será preenchida e cuidada na obra de Proust. Além da brilhante forma de criação de metáforas 
durante toda a sua obra, há vários momentos em que a questão é discutida, não apenas em termos de literatura mas em relação a outras artes.

Em 1920, sua obra, ainda que sujeita a vários reparos, estava quase concluída. Muitos dos recursos que utiliza, ele os percebeu em Flaubert de Madame Bovary e sobretudo de A Educação Sentimental. E são exatamente esses recursos inovadores de Flaubert que serão malcompreendidos pela crítica, sendo apontados como falhas de estilo, como deslizes gramaticais. A narrativa de Flaubert se apresentou ao leitor (e com isso o chocou) de modo a isentar o autor do objeto textual construído e ceder ao próprio discurso a sua autonomia enquanto espaço semiótico, graças a uma consciência e uma competência que lhe favoreceram. Flaubert criava, assim, um discurso intencionalmente singular. Essa singularidade é gerada por uma nova forma de justapor as palavras, de criar efeitos de sentido, de construir sua sintaxe, a sintaxe de uma língua estranha. Evidentemente, houve resistência a essa nova linguagem, uma vez que ela inaugurava um sistema verbal narrativo distinto de toda uma tradição. Como diz Proust, não é na construção de boas metáforas que reside o estilo de Flaubert, mas no tecido da sintaxe, no andamento inusitado das construções, nas ambigüidades do emprego do pronome pessoal, etc.:

"Mas, enfim, a metáfora não é todo o estilo. E não é possível, a quem quer que um dia tenha subido sobre essa grande Esteira rolante que são as páginas de Flaubert, em deslocamento contínuo, monótono, morno, indefinido, desconhecer que elas não têm precedentes na literatura" (loc. cit., p. 67).

Ao falar da não-metáfora em Flaubert, Proust consegue criar a mais definidora de seu trabalho: "esteira rolante". A articulação interna da linguagem, os arranjos das categorias de cada meio expressivo, na busca da ampliação de seus limites - traço condutor da modernidade -, geram uma força diferente, uma convulsão das formas

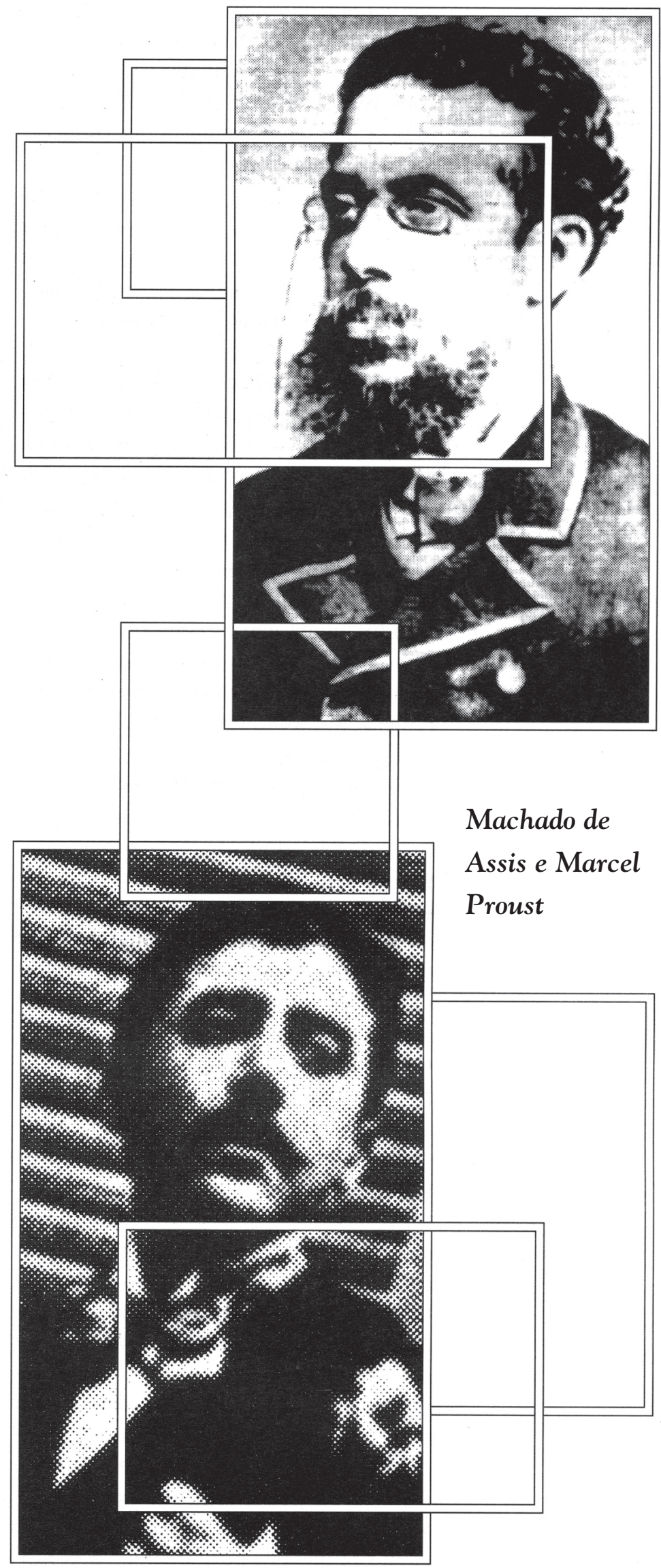


que exigem do receptor uma postura mental diferente. São obras estruturalmente dinâmicas e tematicamente estáticas que, como resultado, geram novas relações, distintas e muito mais intensas que os modelos tradicionais.

A "esteira rolante" utilizada para metaforizar a narrativa de Flaubert caberia, em certa medida, para caracterizar o próprio estilo proustiano. Vale, neste contexto, citar outra assertiva de E. R. Curtius:

“A primeira leitura de Proust produz uma impressão estranha, mescla de encantamento e de confusão. Sentimo-nos envolvidos pela abundância de materiais em aparente desordem, extraviado num estilo prolixo e sinuoso em cujo ritmo não se descobre nenhuma lei; sente-se de uma vez atraído como que pelo timbre de uma música nova cuja harmonia não se consegue analisar; atraído a um universo de sedução tão original, que qualquer um se abandona em seus feitiços" (loc. cit., pp. 14-5).

Muito tem se esforçado a crítica, em busca do "tempo de Proust", entretanto, muito se tem errado, buscando esse tempo na vida do escritor, nos seus hábitos, nos lugares que freqüentava, bem como nas suas idiossincrasias. Além da incongruência de tais procedimentos críticos, pode-se considerar de extrema ironia que alguns críticos se valham, em pleno século XX, de métodos similares àqueles utilizados por SainteBeuve para analisar uma obra que surgiu pela negação do referido método. Todos esses elementos fazem parte do material utilizado para sua moenda inventiva, mas, assim como outros ingredientes, tudo foi metamorfoseado na sua obra em "neblinadas metáforas", fontes de sua "precisão". A respeito de Flaubert, Proust ainda ressalta a sua isenção no modo de narrar e de descrever, assinalando que esse procedimento permite ao autor ir cada vez mais ao encontro do narrador e não do ser histórico Flaubert. Diríamos, em espelho, que o que mais interessa para Proust, e nisso consiste toda a sua busca crítica, é liberar-se cada vez mais daquilo que não é Proust, tornando-se cada vez mais narrador no espaço do discurso ficcional, metafórico, preciso. Faz bem Curtius ao advertir que devemos interpretar essas posições de Proust no sentido de que "a verdadeira crítica tende a descobrir os elementos formais da alma de um autor, e não suas opiniões, nem seus sentimentos". Tender à descoberta dos elementos formais da alma de um autor significa mergulhar nos elementos internos da obra, no seu estilo, pactuando-se o máximo possível com a metáfora do discurso artístico, para que seja viável, uma vez recebida, que ela seja bem percebida.

Dentre as convergências entre os dois escritores uma se destaca: o fato de ambas serem o que Paul Valéry denominaria uma obra clássica.

Cremos ser pertinente ressaltar, ainda, mais um aspecto dentre os vários discutidos no ensaio sobre o estilo de Flaubert. Ao comentar - fato que ocupa grande parte do ensaio - sobre o caráter inovador do uso do pretérito imperfeito pela narrativa flaubertiana, Proust diz o seguinte: “[...] portanto, esse imperfeito, tão novo na literatura, muda inteiramente o aspecto das coisas e dos seres, como uma lâmpada que tenha sido deslocada, à chegada em uma nova casa, a antiga, quando está quase vazia e que se está em plena mudança" (loc. cit., p. 71). Essa idéia capta o verdadeiro sentido da relação entre tradição e modernidade, referindo-se a uma evolução do estilo. A nova casa e a antiga são a mesma, e completamente outra marcada pela poção metamorfoseante e mantenedora do signo do estranhamento, da refração artística, capaz de mobilizar os elementos cristalizados. As formas artísticas de invenção são princípios composicionais ou brechas que desvelam o olho clínico do Homem feito artista, radar captador dos retalhos da realidade. Ao dizermos retalhos da realidade pensamos nas condições básicas sem as quais nenhum trabalho artístico pode se concretizar. Este consiste na consciência de uma meta a atingir que parte da superação das linhas de superfície da realidade, "detrito da experiência" 
para Proust, representado pelos signos emblemáticos, cadaverizados pela convenção. O trabalho ficcional de Marcel Proust evolui num processo de metamorfose inventiva, primeiro de captação, depois de destruição e finalmente de remontagem ou tradução da realidade essencial. Seu princípio de composição, conduzido pela intraduzível busca da Forma do Tempo, faz-se forma espacial, profusa enquanto movimento enlaçado nos entrecruzados nós das veredas da linguagem. "Este trabalho do artista, de buscar sob a matéria, sob a experiência, sob as palavras, algo diferente, é exatamente o inverso do que, a todo instante, quando vivemos alheados de nós, realizam por sua vez o amor-próprio, a paixão, a inteligência e o hábito, amontoando sobre as nossas impressões, mas para no-las esconder, as nomenclaturas, os objetivos práticos a que erradamente chamamos vida" (T.R., p. 142). A busca sob e não sobre constitui um universo que transcende a ele próprio por ir, o máximo possível, nas profundezas do verdadeiro eu. Dizendo assim, tentando driblar a palavra-chave que define esta obra: uma poética, no sentido de elevação da potência da linguagem, sem atributos, possuindo, portanto, a mais rigorosa precisão. É correto Roland Barthes ao definir À la Recherche du Temps Perdu como a história de uma escritura. Esta história é o estéril pretexto que vai deixando para amanhã, sempre numa posição de adiamento, uma possível obra literária. Entretanto, ao pairar no tempo, À la Recherche du Temps Perdu, os signos deixam seus rastros e estes apreendem o sentido da vida, na outra esfera do tempo. É sem sair do círculo que nasce a obra; ela resgata o acento da verdade. Todavia, o resultado deste processo teve seu momento de efervescência bem antes. Ele não surgiu ao acaso. Resulta de obras anteriores, de um verdadeiro laboratório de experiências literárias incluindo ensaios, pastiches e ficção. As obras que o compõem são: Les Plaisirs et les Jours; Jean Santeuil; Pastiches et Mélanges; Contre SainteBeuve e Essais et Articles.

\section{PRESENCA DE OUTROS SISTEMAS NO ESTILO DE MARCEL PROUST}

O discurso proustiano é um mundo que resguarda muitas moradas com seus nichos, recantos sombrios, naves abertas e labirínticas, como construções medievais. Exige, por isso mesmo, disponibilidade e exercício do espírito, para que suas “chaves mágicas" sejam encontradas. Se a grande maioria da atenção crítica se volta para a obra principal, isto é, para os sete volumes que compõem À la Recherche du Temps Perdu, não se pode deixar de entender que essas contínuas, monótonas e infindáveis páginas travam interessantíssimo coerente diálogo com outros escritos do autor e é por meio desse diálogo que muitos fatores determinantes da construção modulada de seu pensamento estético emergem ao leitor, ou passam a ser melhor compreendidos. Marcel Proust viveu e produziu literatura num dos momentos mais efervescentes da cultura ou do metamorfoseamento da cultura ocidental. Parece ter herdado com a devida sagacidade dos gênios, ou melhor, parece ter sabido conduzir, de maneira muito especial, a tocha olímpica da linguagem, incendiando bosques da tradiçãoe ampliando as veredas da modernidade. Seu olho é similar ao da lanterna mágica; é o olho de um genuíno mestre da modernidade crítico-inventiva, que soube, no seu médio tempo de vida, perceber na devida medida o movimento das coisas com que lidou. Isso quer dizer que, como já vimos, Proust foi, antes de tudo, grande e versátil leitor. Leitor dos clássicos, leitor dos modernos, leitor dos maiores e leitor dos menores, leitor de literatura, mas, com a mesma argúcia crítica, foi um grande leitor dos outros sistemas artísticos, como da arquitetura, sobretudo a medieval, da pintura, da música, do teatro e, pelo resultado de sua obra, mostra ter compreendido a profunda homologia que se estabelece entre os vários sistemas, fazendo com que convergissem paro o meio expressivo de que se valeu: a literatura. 
Dito de outro modo, os vários sistemas parecem ter auxiliado Proust, dentro dos procedimentos expressivos que lhes são próprios, na "fabricação" não da literatura, mas da "arte verbal", capaz de dialogar, o tempo todo, com as demais artes, no fluxo ininterrupto de sua narrativa. Esse leitor privilegiado tornou-se um grande crítico e foi no perímetro da crítica que construiu o seu sistema ensaístico-ficcional. Sendo assim, crítica e invenção implicam-se e se opõem de tal modo na escritura deste artista, que se torna inconcebível a vã tentativa de se entender uma, sem ter a devida consciência da outra e vice-versa. Diríamos que Proust conseguiu atingir o que se poderia chamar de precisa instabilidade do discurso.

Já seus primeiros estudiosos, mesmo que para criticá-lo, apontavam para esse fenômeno de seu trabalho em que estabelece as mais variadas relações de sentido por meio dos vários códigos artísticos. Mais que a demonstração de uma erudição sobre o mundo da literatura e das artes, os vários sistemas parecem compor a unificação estética desse pensamento. Ao ver o processo de realização proustiano e penetrar nos meandros dos sentidos por ele instaurados, torna-se quase imediata a associação que se processa entre esse universo e aquele de Leonardo Da Vinci, que serviu de mote ou de fonte inspiradora para Paul Valéry desenvolver um dos seus mais completos e profundos ensaios sobre estética. Refiro-me ao Introdução ao Método de Leonardo Da Vinci. Gostaria também de retomar Ernst-Robert Curtius, que num breve capítulo denominado "O Estilo", pertencente ao referido livro Marcel Proust e Paul Valéry, revela sua forte impressão pela habilidade de Proust ao lidar com a frase, com o epíteto e, sobretudo, com a metáfora. Ele se manifesta passional - algo interessante para alguém com sua capacidade de explicar - com aquilo que o estilo do narrador revela. Cita uma grande passagem do texto proustiano como se fosse impossível descrever o fenômeno: "Porém deixemos que seja o próprio Proust quem nos dê a resposta e veja- mos o que uma nova forma de expressão pode conseguir dessa situação". Ao descrever a passagem descrita por Proust de uma situação anteriormente imaginada por Curtius, o filólogo, ao invés de analisá-la, continua tentando de maneira passional, valendo-se de imagens que possam responder os procedimentos desse estilo tão marcante e original. E é dessa "passionalidade" que emergem os pontos fulcrais a que aludi, na leitura de Curtius. Dentre elas, destaca-se a aproximação que ele faz do estilo de Proust com a pintura de Monet e a música de Debussy. Mesmo se tratando de um ensaio tão antigo, um dos primeiros de maior fôlego sobre o discurso proustiano, as relações associativas com as demais artes se deram de maneira quase instantânea. Curtius, evidentemente, não aprofunda a análise, mas fornece elementos de entrada para aspectos de suma importância, presentes no sistema de Proust. Mais tarde Muchel Butor realizará um brilhante estudo sobre os três sistemas artísticos (literatura, música e pintura), considerando-os as três grandes vertentes que regem À la Recherche du Temps Perdu.

Dentre os críticos modernos, gostaríamos de destacar uma obra das mais representativas que influenciou sobremaneira nossas abordagens críticas sobre o escritor francês, no que diz respeito à construção de seu pensamento estético. Trata-se do ensaísta francês Luc Fraisse, autor de outros estudos fundamentais sobre Proust, mas que em L'Oeuvre Cathédrale-Proust et l'Architecture Médievale, de 1989, publicado por José Corti, conseguiu realizar um trabalho iluminador, dotado de uma intensidade rara nas abordagens, principalmente no que concerne às aproximações entre o discurso verbal e os demais discursos. O trabalho de Fraisse apresenta uma verdadeira arqueologia de $\grave{A} l a$ Recherche du Temps Perdu, marcada pela força da originalidade, uma vez que tenta demonstrar as correspondências entre a obra verbal de Proust e a macro e microestrutura das catedrais medievais. Como se fosse um dicionário arquitetônico, realizado inclusive por ordem alfabé- 
tica, cada uma de suas partes corresponde a uma das partes de uma catedral medieval e, em cada uma delas, o pesquisador desenvolve suas considerações críticas, articulando a estrutura da obra proustiana à estrutura dos elementos composicionais da arquitetura.

No caso da pintura, a concepção de Marcel Proust se integra à sua concepção de museu. Torna-se praticamente impossível adentrarmos o universo verbal e/ou ficcional de Proust sem tentarmos compreender o universo semiológico que compõe seu pensamento. Os sentidos de sua narrativa, ou os sentidos da teia que o escritor francês articula, com o pretexto de estar realizando uma escritura, advêm de procedimentos variados, diríamos de uma espécie de cruzamento de metáforas, que tem como fio condutor o signo da arte, lembrando sempre a feliz expressão de Gilles Deleuze. Proust cria uma espécie de movimento de existências que se inter-relacionam, para que seja possível dar o verdadeiro movimento à própria arte. Fez da arte signo dela mesma. Só assim conseguiu conjugar invenção e reflexão, ou vice-versa. Mais ainda: as sequiências narrativas de À la Recherche du Temps Perdu são espécies de simulacros narrativos que jamais poderiam ser enfabulados uma vez que a origem de seu fluxo não tem como matéria-prima núcleos enfabulativos, mas signos artísticos ou signos extraídos da própria condição da arte. É assim que os verdadeiros índices, os mais perspicazes que podem nos conduzir às questões mais decisivas da arte podem ser encontrados nessa crítica de invenção e não na grande maioria dos livros de história da arte. Entretanto, tal processo se apresenta imbricado e complexo e não pode ser resolvido, criticamente, de maneira linear. Para que bem se compreendam determinados movimentos que conduzem aos efeitos mais decisivos da obra, é necessário que o leitor tenha muito bem trilhado todos os percalços que o conduzem àquela condição de leitor, não diríamos ideal, mas que tangencia o movimento de dialogismo com a obra em questão.
A pintura não consiste, nessa obra, numa presença e sim numa espécie de elemento conjuntivo do teatro de signos que o artista e ensaísta Marcel Proust inventou. Dir-se-ia que todo o processo articulatório de sua obra se desenvolve a partir da própria ficção, ou melhor, o resgate da vida se dá de dentro das obras ou pelas reflexões advindas das obras de arte. E a pintura ocupa um lugar de destaque, respeitada por sua natureza sincrética, pelo simultaneísmo de seus elementos. O que se nota ao longo da narrativa proustiana é uma espécie de história sincrônica da pintura posta numa condição de movimento. É ilusório crer que se trata de uma visão de Proust sobre uma determinada escola de pintura, posição assumida por grande parte de seus críticos O que ocorre é uma manifestação crítica da parte do inventor-crítico Marcel Proust em relação à pintura de todos os tempos. Selecionam-se obras e, conseqüentemente, autores e não uma época específica. Proust demonstrou na sua vida de intelectual, sobretudo nos últimos anos de sua existência, possuir verdadeira rejeição por certas posições críticas sobre pintura. Ele se vale da pintura como signo permeado de sentidos que entram em sintonia com os demais signos de seu discurso. Isso traz uma implicação determinante no conjunto de sua obra. É certo que há atualmente alguns estudos que se voltam para a manifestação da pintura no seu trabalho. Entretanto o que queremos apontar não é a presença ou o levantamento de todas as manifestações plásticas ao longo de À la Recherche du Temps Perdu, mas o modo como o sistema plástico participa do movimento dos sentidos nesta grande invenção literária. Ao longo da obra, são várias as formas de manifestação do sistema plástico. Encerraria estas reflexões dizendo que se Marcel Proust regeu tão magistralmente a palavra não terá sido a palavra que norteou o diagrama mental na fabricação de seu sistema poético. O seu norteador foi irremediavelmente a imagem. 


\section{BIBLIOGRAFIA}

BARTHES, R. "Proust et les Noms", in . Le Degré Zéro de l'Écriture Suivi de Nouveaux Essais Critiques. Paris, Éditions du Seuil, 1972, p. 121-34.

. Crítica e Verdade. Trad. bras. de Geraldo Gerson de Sousa. São Paulo, Perspectiva, 1982.

BAUDELAIRE, C. "Critique d'art", in Oeuvres Complètes. Texte établi, présenté et annoté par Claude Pichois. Paris, Gallimard, 1976, tome II, pp. 351-775.

. "Salon de 1845", in Oeuvres Complètes. Texte établi, présenté et annoté par Claude Pichois. Paris,

Gallimard, 1976, tome II, pp. 351- 407. "Salon de 1846", in Oeuvres Complètes. Texte établi, présenté et annoté par Calude

Pichois. Paris, Gallimard, 1976, tome II, pp. 415-96.

"Le Peintre de la Vie Moderne", in . Oeuvres Complètes. Texte établi, présenté et

annoté par Claude Pichois. Paris, Gallimard, 1976, tome II, pp. 683-724.

BENJAMIN, W. "Sobre alguns Temas em Baudelaire", in W. Benjamin et al. Textos Escolhidos. Trad. bras. de Atilia B. Fiori. São Paulo, Abril Cultural, 1975, pp. $35-62$ (Os Pensadores).

BONNET, Henri. Marcel Proust de 1907 a 1914. Paris, Nizet, 1959. Apud Taeko Uenishi. Le Style de Proust et la Peinture. Paris, Sedes, 1988.

BUTOR, M. "Les Sept Femmes de Gilbert La Mauvais, Autre Heptaédre", in L' Arc, no 47, "Proust", 1971, pp. 33-45. Apud J. Kristeva. Le Temps Sensible: Proust et l'Expérience Littéraire. Paris, Gallimard, 1994, (NRF éssais).

CLARAC, P. "Introdução do Editor Francês", in M. Proust. Contre Sainte-Beuve: Notas sobre Crítica e Literatura. Trad. bras. de Haroldo Ramanzini. São Paulo, lluminuras, 1988, pp. 25-36.

CURTIUS, R.E. Marcel Proust y Paul Valéry. Buenos Aires, Editorial Losada, 1941.

DELEUZE, G. "Os Signos da Arte e a Essência", in Proust e os Signos. Trad. bras. de A. C. Piquet e R.

Machado. Rio de Janeiro, Forense Universitária, 1987, pp. $39-51$ (4@ ed. atualizada, 1987, Presses Universitaires de France).

FRAISSE, L. L'Oeuvre Cathédrale: Proust et l'Architecture Mediévale. Paris, José Corti, 1990.

FRYE, Nortroph. "Introdução Polêmica", in Anatomia da Crítica. Trad. bras. de Péricles Eugênio da

Silva Ramos. São Paulo, Cultrix, 1973, pp. 11-36.

GALLIMARD, G. (Le gérant). La Nouvelle Revue Française. Hommage à Marcel Proust (1871-1922). Paris, Gallimard, no 112, 1 er. janvier 1923 (nouvelle impréssion 1991).

GONÇALVES, A. "O Processo Holometabólico em Marcel Proust", in M. Proust. Contre Sainte-Beuve. Trad. bras. de Haroldo Ramanzini. São Paulo, lluminuras, 1988, pp. 7-24.

KRISTEVA, J. Le Temps Sensible: Proust et l'Expérience Littéraire. Paris, Gallimard, 1994, (NRF éssais).

LESSING, E. Laocoonte - 0 sobre los Límites de la Pintura y la Poesia. Trad. do alemão, prólogo e notas de Enrique Palau. Barcelona, Editorial Iberia, 1957.

MALLARMÉ, S. Oeuvres Complètes. Texte établi et annoté par Henri Mondor et G. Jean Aubuy. Paris, Gallimard, 1945.

PAINTER, G. Marcel Proust. les Années de Jeunesse (1871-1903). Traduit de I'anglais par G. Cattaui et R.P Vial. Paris, Mercure de France, 1966, pp. 348-9.

PROUST, M. À la Recherche du Temps Perdu. Paris, Gallimard, 1987-89. Le Temps Retrouvé, in À la Recherche du Temps Perdu: Albertine Disparue; Le Temps

Retrouvé. Paris, Gallimard, 1989, vol. 4, pp. 273-625 (Bibliothèque de La Pléiade). . No Caminho de Swann. 9 ed. Trad. bras. de Mário Quintana. Porto Alegre, Globo, 1973. 
. 0 Caminho de Guermantes. 3 ed. Trad. bras. de Mário Quintana. Porto Alegre, Globo, 1972.

À Sombra das Raparigas em Flor. 2 ed. Trad. bras. de Mário Quintana. Porto Alegre, Globo, 1973.

. A Prisioneira. Trad. bras. de Lourdes Sousa de Alencar e Manuel Bandeira. Porto Alegre, Globo, 1971,

p. 135.

. 0 Tempo Redescoberto. Trad. bras. de Lúcia Miguel Pereira. Porto Alegre, Globo, 1970.

Jean Santeuil. Trad. bras. de Fernando Py. Rio de Janeiro, Nova Fronteira, 1982.

. Sur la Lecture, in J. Ruskin. Sésame et les Lys. Traduction et notes de M. Proust. Paris, Éditions

Complexes, 1987, pp. 35-97.

. Contre Sainte-Beuve: Notas sobre Crítica e Literatura. Trad. bras. de Haroldo Ramanzini. Pref. de

Aguinaldo José Gonçalves. São Paulo, lluminuras, 1988.

"Sobre a Arte: para Jacques-Émile Blanche", in

Nas Trilhas da Crítica. Trad. bras. de

Plínio Augusto Coelho. São Paulo, Edusp/Imaginário, 1994, pp. 41-63.

."A Propósito do Estilo de Flaubert", in

Nas Trilhas da Crítica. Trad. bras. de Plínio

Augusto Coelho. São Paulo, Edusp/Imaginário, 1994, pp. 65-85.

. "A Propósito de Baudelaire", in Nas Trilhas da Crítica. Trad. bras. de Plínio Augusto

Coelho. São Paulo, Imaginário, 1994, pp. 103-35.

. "Lettre de 18 mars, 1908 à Robert Dreyfus". Apud P. Clarac. "Introdução do Editor Francês", in M.

Proust. Contre Sainte-Beuve: Notas sobre Crítica e Literatura. Trad. bras. de Haroldo Ramanzini. São Paulo,

lluminuras, 1988, pp. 25-36.

RUSKIN, J. Sésame et les Lys. Traduction et notes de M. Proust. Paris, Éditions Complexes, 1987.

. As Pedras de Veneza. Trad. bras. de Luís Eduardo de Lima Brandão. São Paulo, Martins Fontes, 1992.

SAINTE-BEUVE, C. "Causéries du Lundi: les Contemporains de Sainte-Beuve", in B. Lalande (org.). Paris, Larousse,

1953, tome 124, partie II (Collection Classiques Larousse).

SHATTUCK, R. As Idéias de Proust. Trad. bras. de Eliani Fittipaldi Pereira. São Paulo, Cultrix/Edusp, 1985.

UENISHI, Taeko. Le Style de Proust et la Peinture. Paris, Sedes, 1988.

VALÉRY, P. "Introduction à la Méthode de Léonard de Vinci", in . Variété I. Paris, Gallimard, 1924, pp.

98-107. 